\section{At skrive er at plante et frø}

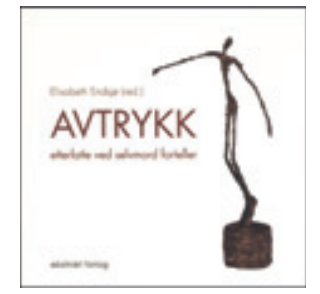

\section{Elisabeth Endsjø, red Avtrykk}

Etterlatte ved selvmord forteller. $156 \mathrm{~s}$, ill. Oslo: Abstrakt forlag, 2011. Pris NOK 265 ISBN 978-82-7935-311-9

Bogen består af korte tekster og en enkelt fotoserie, alle skabt af norske efterladte efter selvmord. Teksterne beskriver livet efter selvmordet, og de efterladte har aktivt brugt skrivning som et redskab til at bearbejde chok og sorg i et forsøg på at forsone sig med tabet.

Udgangspunktet er skriveprojektet «Skabende ressourcegruppe for efterladte efter selvmord», som blev gennemført i 2009. Her medvirkede 13 kvinder og tre mænd i alderen 28-70 år. Målet var at udvikle tekster til en bog møntet på andre efterladte efter selvmord, baseret på deltagernes egne erfaringer.

De korte tekster veksler mellem prosa og digt - i et par tilfælde ganske få linjer, sendt som SMS! Mange tekster fylder kun én enkelt side. Denne grafiske enkelhed og variation gør bogen let tilgængelig, og denne tilgængelighed kan være en styrke, hvis man tænker, at læseren ikke leder efter faglitteratur om efterladte og selvmord, men mere efter andre typer ressourcer, de skabende. Projektleder og bogens redaktør, Elisabeth Endsjø, har valgt en forsideillustration af en skulptur af Alberto Giacometti (1901-66) - Falling man og dermed slår hun den skabende tone an. Giacomettis skrøbelige figurer er for hende et billede på menneskets sårbare og vaklende styrke, og det er et godt billede på styrken i bogens tekster, for de pendler alle mellem meget modsatrettede følelser - præcis som beskrevet af Marianne W, der har mistet sin far:

Jeg er trist, men lettet

Jeg er glad, men bekymret

Jeg er utmattet, men håpefull

Jeg er sint, men forstår

Jeg vil ikke synes, men vil bli sett

Se meg

Bogen er ikke for dem, der ønsker enkle opskrifter på, hvordan livet efter selvmordet kan gå videre. Teksterne er smertefuld læsning, og de viser at der aldrig er nogen simpel måde at komme videre på, men de viser også at der er muligt at leve med hele spekteret af stærke og ofte modstridende følelser, og at der er hjælp at hente.

Den er også relevant for fagpersoner, for hvis man som fagperson fornemmer at fx skrivning, tegning, fotografering eller andre former for skabende ressourcer kan komme den efterladte til gavn, så er det en fremragende bog at henvise til.

Gruppens skrivelærer, Merete Morken Andersen, står bag et meget spændende kapitel, hvor hun forklarer om strategien bag dette at finde ord og få ordene til at leve - og om hvad hun gjorde i gruppen, når modstanden mod at skrive dominerede, og deltagerne blev ramt af et indre eller ydre forventningspres.

«At være skabende vil blandt andet sige at klare at rumme og omdanne smertefulde erfaringer til ressourcer, som noget nyt kan blive født af,» skriver hun - og bogen er et godt bevis på hvordan levende ord, enkle og direkte, kan bruges til at omdanne onde erfaringer til noget som kan bruges af andre.

\section{Langt fra skreddersydd}

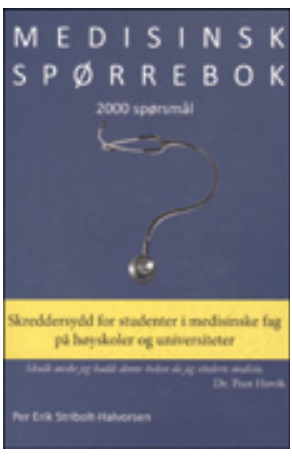

Per Erik Stribolt-Halvorsen

202 s. Oslo: Fritt Forlag, 2011. Pris NOK 249 ISBN 978-82-8179-062-9

Omslaget har en vakker gråblå farge. «Skreddersydd for studenter i medisinske fag på høyskoler og universiteter» står det skrevet på et sitrongult bånd som effektivt skaper en kontrast til det blå underlaget. Påstanden kunne vært enda lenger unna sannheten, men den kunne også vært atskillig nærmere. Kan man skreddersy et produkt som skal passe alle individer i så mange ulike kategorier? Et sitat fra dr. Peer Høvik, «Skulle ønske jeg hadde denne boken da jeg studerte medisin», som også kler forsiden, bidrar ikke til å øke troverdigheten.

Problemet er at Medisinsk spørrebok mangler et fokus. Hvis man skal kunne bruke en slik bok effektivt som student, må man vite at den dekker et bestemt område på en noenlunde konsistent måte. Gjør den det? Boken inneholder 2000 spørsmål med svar og er delt inn i områdene kjønnsorganene, endokrinologi, immunologi, sansene, huden, ernæring, fordøyelsen, blodet, respirasjon, sirkulasjonssystemet, nyrer/urinveier, nervesystemet, skjelettet, muskulatur, syre/base og cellebiologi. Spørsmålene i seg selv virker greie nok, men de er for overfladiske i forhold til hva for eksempel en medisinstudent skal kunne. Det kan også virke som om forfatteren har anstrengt seg for å formulere spørsmålene i et språk som ligger så nært dagligtale som mulig. Ett av omkring 150 spørsmål om sirkulasjonssystemet er for eksempel formulert slik: «Hva heter arterien som forsyner benene med blod?». Dette er ikke godt språk, man kunne i det minste skrevet beina eller underekstremiteten. «Med blod» fremstår også som unødvendig, rent språklig sett. Hvis det ikke var blod arterien forsynte «benene» med, hva skulle det da være? På grunn av det dårlige språket blir også gyldigheten av svaret, a. femoralis, uklart. Grener fra a. iliaca interna forsyner flere av hofteleddets muskler. Hører disse også med til «benene»?

En spørrebok som faktisk var skreddersydd for studenter i medisinske fag, ville nok kunne fylle en funksjon. Det sier seg selv at en slik bok måtte utformes separat for hvert enkelt studium. I forhold til medisinstudiet kunne en slik bok vært organisert med utgangspunkt i de om lag 30 fagene på studiet, slik at spørsmålene dekket hva man forventes å kunne i hvert enkelt fag. Videre måtte hver fagbolk inndeles, slik at man kunne finne frem ut fra hvor i studiet man befinner seg. Å bedrive slik skreddersøm ville kreve tid og ressurser som jeg tviler på at Fritt Forlag har hatt intensjoner om å legge inn i dette bokprosjektet. Hvis de ikke hadde fremstilt det som om det var skreddersøm de bedrev, ville de fremstått som mer seriøse enn de gjør med denne utgivelsen.

Tore Næss

Stud.med.

Redaktør for ÆEsculap 